\title{
A Measurement Technique to Determine the Sensitivity of Trained Dogs to Explosive Vapor Concentration
}

\author{
J. E. Reaugh, J. W. Kury
}

April 2, 2002

U.S. Department of Energy

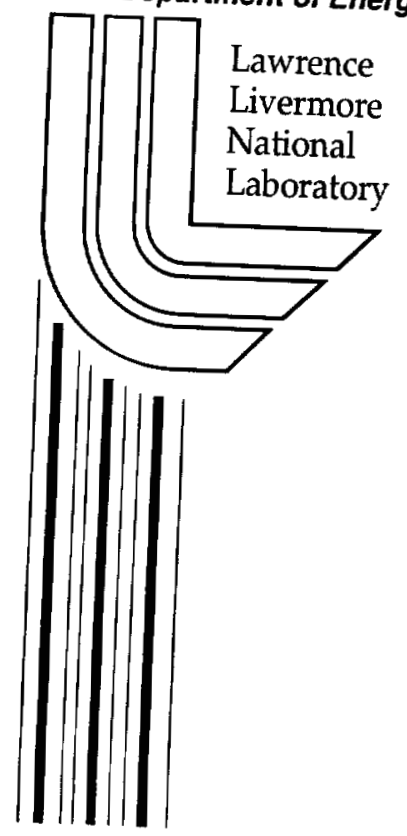




\section{DISCLAIMER}

This document was prepared as an account of work sponsored by an agency of the United States Government. Neither the United States Government nor the University of California nor any of their employees, makes any warranty, express or implied, or assumes any legal liability or responsibility for the accuracy, completeness, or usefulness of any information, apparatus, product, or process disclosed, or represents that its use would not infringe privately owned rights. Reference herein to any specific commercial product, process, or service by trade name, trademark, manufacturer, or otherwise, does not necessarily constitute or imply its endorsement, recommendation, or favoring by the United States Government or the University of California. The views and opinions of authors expressed herein do not necessarily state or reflect those of the United States Government or the University of California, and shall not be used for advertising or product endorsement purposes.

This work was performed under the auspices of the U.S. Department of Energy by the University of California, Lawrence Livermore National Laboratory under Contract No. W-7405-Eng-48.

This report has been reproduced directly from the best available copy.

Available electronically at http://www.doc.gov/bridge

Available for a processing fee to U.S. Department of Energy

And its contractors in paper from

U.S. Department of Energy

Office of Scientific and Technical Information

P.O. Box 62

Oak Ridge, TN 37831-0062

Telephone: (865) 576-8401

Facsimile: (865) 576-5728

E-mail: reports@adonis.osti.gov

Available for the sale to the public from

U.S. Department of Commerce

National Technical Information Service

5285 Port Royal Road

Springfield, VA 22161

Telephone: (800) 553-6847

Facsimile: (703) 605-6900

E-mail: orders@ntis.fedworld.gov

Online ordering: http://www.ntis.gov/ordering.htm

\section{OR}

Lawrence Livermore National Laboratory

Technical Information Department's Digital Library

http://www.llnl.gov/tid/Library.html 


\section{Introduction}

Over the years canines have been used successfully to detect explosives. However, exactly what a canine detects in the many thousands of explosive formulations available is still not well understood. LLNL and Bureau of Alcohol, Tobacco and Firearms (BATF) studies over the past four years are beginning to provide better insight into this complex problem.[1]

One area that has been addressed is how low a molecular concentration of nitromethane explosive can a canine detect. Forty-one canine/handler teams were used in four test series with arrays containing dilute nitromethane-in-water solutions. (The canines had been trained on the amount of nitromethane vapor in equilibrium with the undiluted liquid explosive.) By diluting liquid nitromethane with water, the amount of explosive vapor can be reduced many orders of magnitude to test the lower limit of the canine's nitromethane vapor detection response. The results are summarized in the table in Appendix A. The probability of detecting nitromethane remained high until the vapor pressure fell below $\sim 1 \times 10^{-6}$ microns (one nitromethane molecule in a trillion nitrogen, oxygen and water molecules).

This report describes a new approach to measuring this lower limit of detection using the diffusion of nitromethane in various length tubes containing air.

\section{Method}

We assume an equipment set up illustrated schematically in Figure 1 where a replaceable sample holder is attached to a length of PVC piping, that contains a test port at some distance from the sample holder.

At the surface of the sample in the sample holder, the vapor pressure of test material is at its equilibrium value. From the boundary condition that the concentration of the test material is determined by its vapor pressure, the concentration along the pipe can be determined. We solve the 1-dimensional diffusion equation in slab geometry, subject to the condition that the concentration at one boundary $(x=0)$ is fixed, and the concentration is initially 0 everywhere else. The closed form solution [2] is

$$
v(x, t)=V \operatorname{erfc}\left(\frac{x}{2 \sqrt{\kappa t}}\right)
$$

where $V$ is the concentration at the evaporating surface of the sample, $x$ is the distance along the pipe, $t$ is time, $\kappa$ is the diffusivity of the sample material in air, and $v$ is the time-and-space dependent concentration. At long distances and short times, the asymptotic form of the complementary error function is [2]

$$
\operatorname{erfc}(x)=\pi^{-1 / 2} e^{-x^{2}}\left(\frac{1}{x}-\frac{1}{2 x^{3}}+\ldots\right)
$$

We use a correlation presented in [3] to define the diffusivity,

$$
\kappa=p^{-1} a\left(\frac{T}{\sqrt{T_{c A} T_{c B}}}\right)^{b}\left(p_{c A} p_{c B}\right)^{0.3333}\left(T_{c A} T_{C B}\right)^{0.4167}\left(\frac{1}{M_{A}}+\frac{1}{M_{B}}\right)^{0.5}
$$


where $p$ is the pressure ( $\mathrm{atm}), T$ is temperature $(\mathrm{K}), M$ is molecular weight, the subscript $c$ refers to the critical point, and the subscripts $A$ and $B$ refer to the sample material and to air. For non-polar gas pairs, the parameter $a$ is $2.745 \times 10^{-4}$, and $b$ is 1.823 For air, $p_{c}$ is $36.4 \mathrm{~atm}, \mathrm{~T}_{c}$ is $132 \mathrm{~K}$, and $M$ is 28.97

We consider nitromethane as the sample material. The critical pressure and temperature are $62.3 \mathrm{~atm}, 588 \mathrm{~K}$ [4], and $M$ is 61 . That reference also gives the vapor pressure as

$$
\log _{10} P=(-0.2185 A / T)+B
$$

where for nitromethane, $A=9210.9, B=8.21936$. $P$ is the pressure in Torr. For this case, the diffusivity of nitromethane in air is $0.0972 \mathrm{~cm}^{2} / \mathrm{s}$. the partial pressure at $293 \mathrm{~K}$ is $0.0295 \mathrm{~atm}$. For perfect gases, the partial pressure is proportional to the molar concentration, so that we can express the concentration as the fraction of an atmosphere. Figure 2 shows the time at various distances along the pipe that a specified vapor pressure (atm) appears. From this result, a $1.5 \mathrm{~m}$ (5-foot) pipe shows a vapor pressure increasing from $10^{-10} \mathrm{~atm}$ to $10^{-6} \mathrm{~atm}$ from one to two hours after the sample begins to evaporate. The earliest time that a trained canine would indicate explosive could be interpreted as the partial pressure that it is responding to.

\section{Effect of test temperature}

There is a small but noticeable effect of the temperature at which the test is being conducted, as it affects both the diffusivity and the vapor pressure of nitromethane. At $30^{\circ} \mathrm{C}$, compared to $20^{\circ} \mathrm{C}$, the arrival of a concentration at the 5-ft (1.5-meter) station is about 3 minutes earlier (at 42 minutes instead of 45 minutes) for a concentration of $10^{-12} \mathrm{~atm}$.

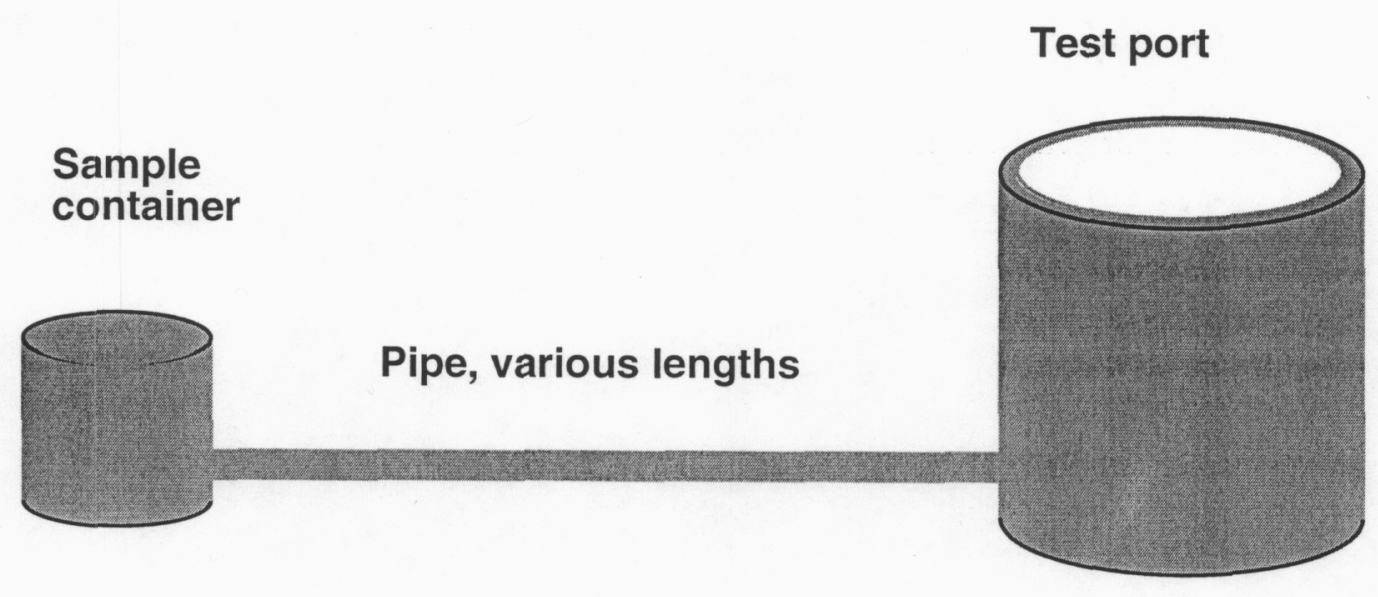

Figure 1. Schematic of apparatus. Nitromethane evaporates from the bottom of the sample container and diffuses down the pipe to the test port. 


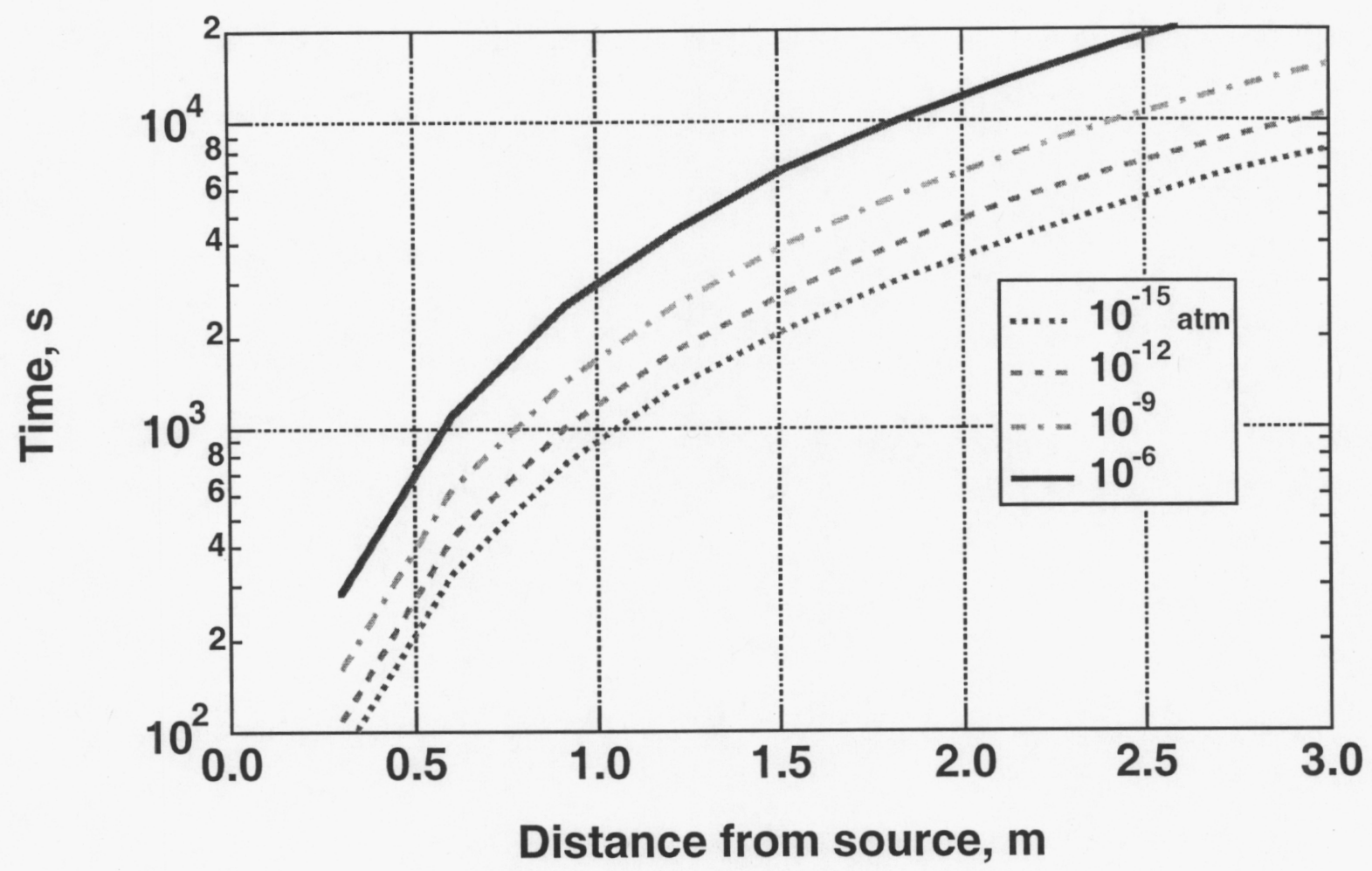

Figure 2. Time of arrival of indicated nitromethane vapor pressure at a test port located at various distances from the sample

\section{Effect of sample container}

We also performed a sequence of numerical simulations to assess the effect of locating the pipe connecting the source to the test port at some distance above the level of the test material (nitromethane). For the case we examined, there was an approximately constant delay relative to a calculation where the surface of the evaporating fluid was at the entrance to the pipe. The delay, which corresponded to a constant distance for all concentrations, was just the distance between the pipe entrance and the surface of the evaporating fluid, on the order of a few $\mathrm{cm}$.

\section{Considerations for engineering and design}

Since there is a strong possibility of contamination, the test apparatus should be inexpensive enough that one-time use is practical. Robert Augur, of Van Aiken International, Rancho Cucamonga, CA designed and constructed the apparatus, illustrated in Figs 3-5. His estimate is that they can be constructed for about $\$ 10$ each. 


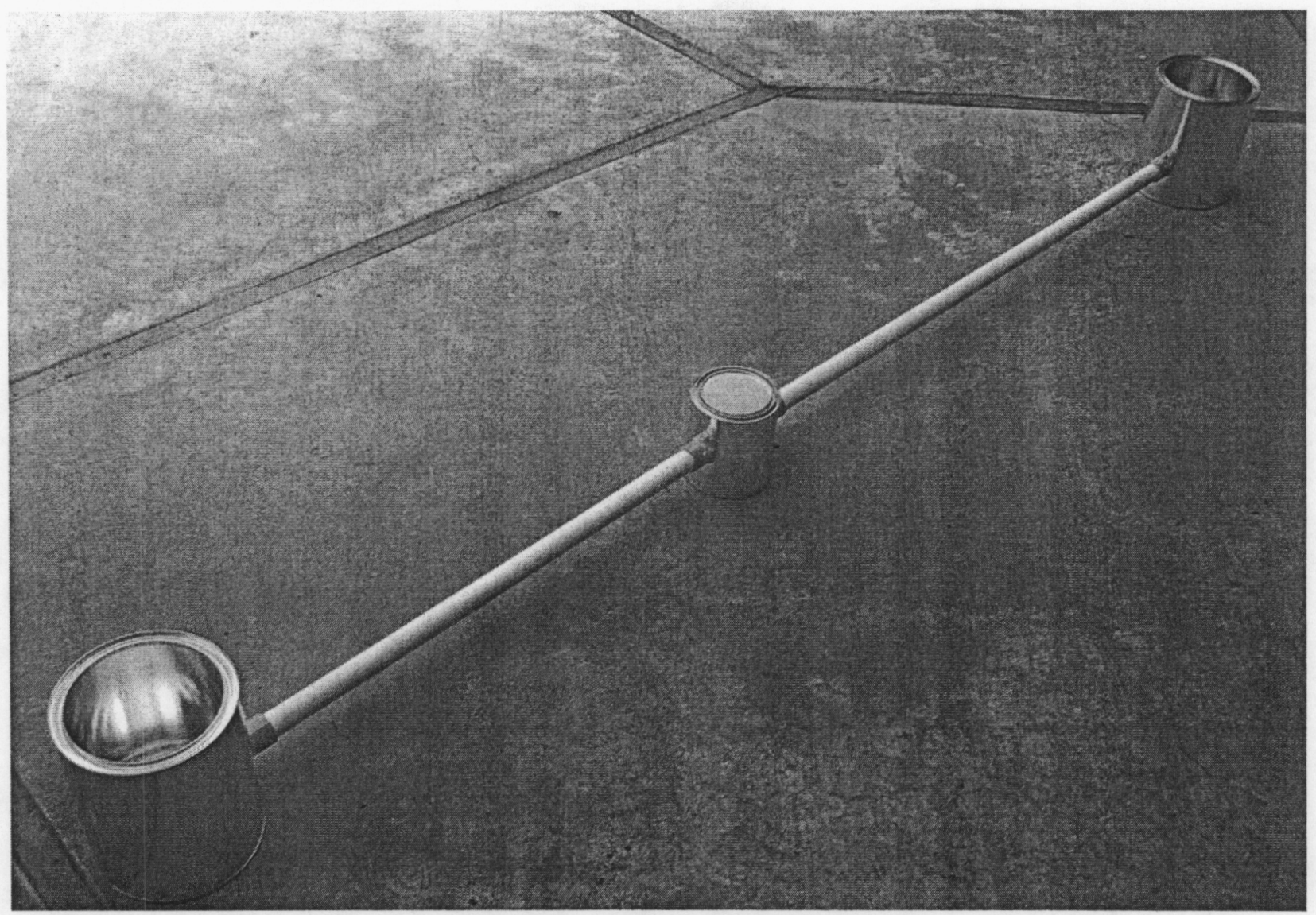

Figure 3 Constructed apparatus with central sample holder and two test ports 


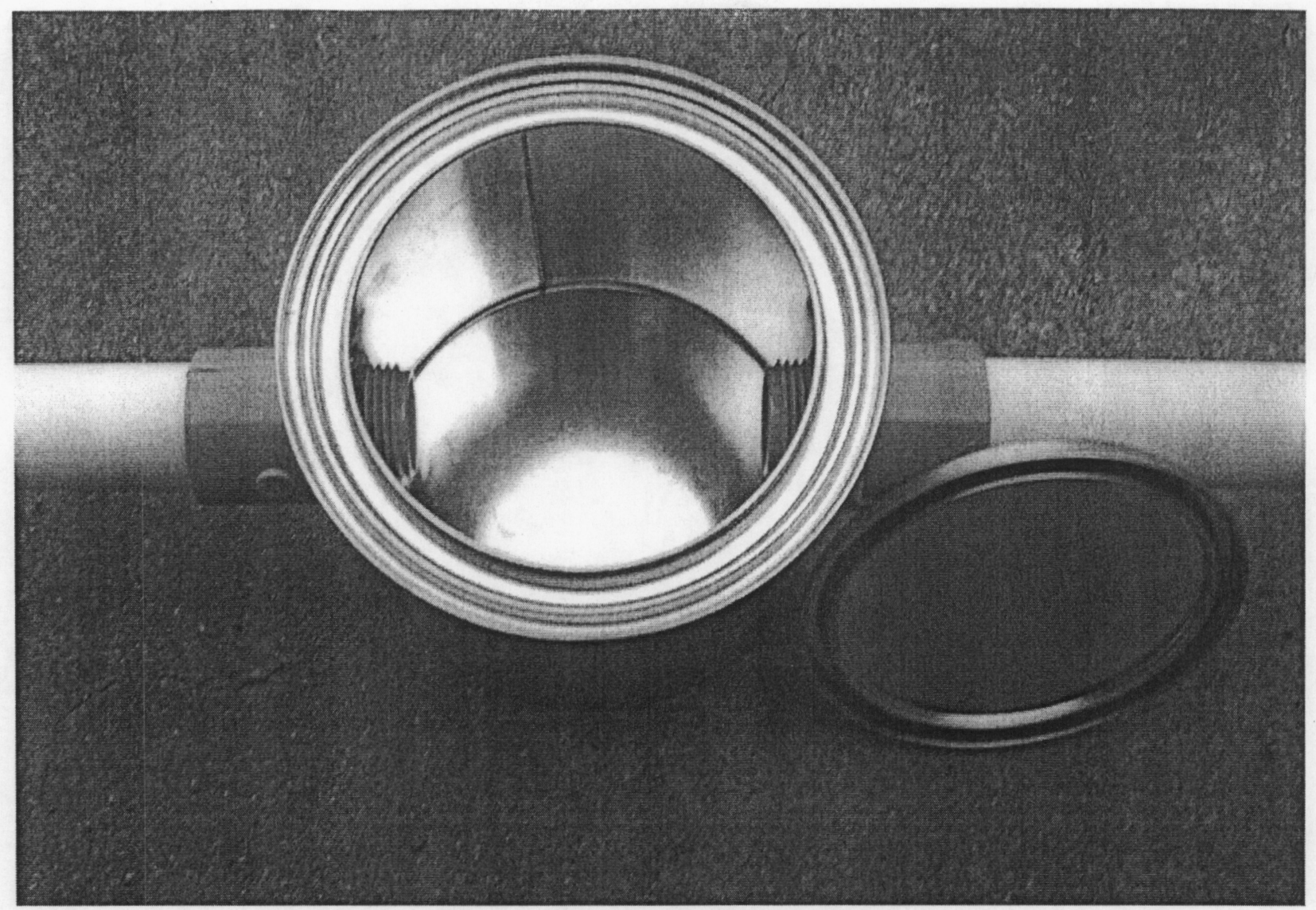

Figure 4. Sample container with lid for sealing the container (1-quart paint can) 


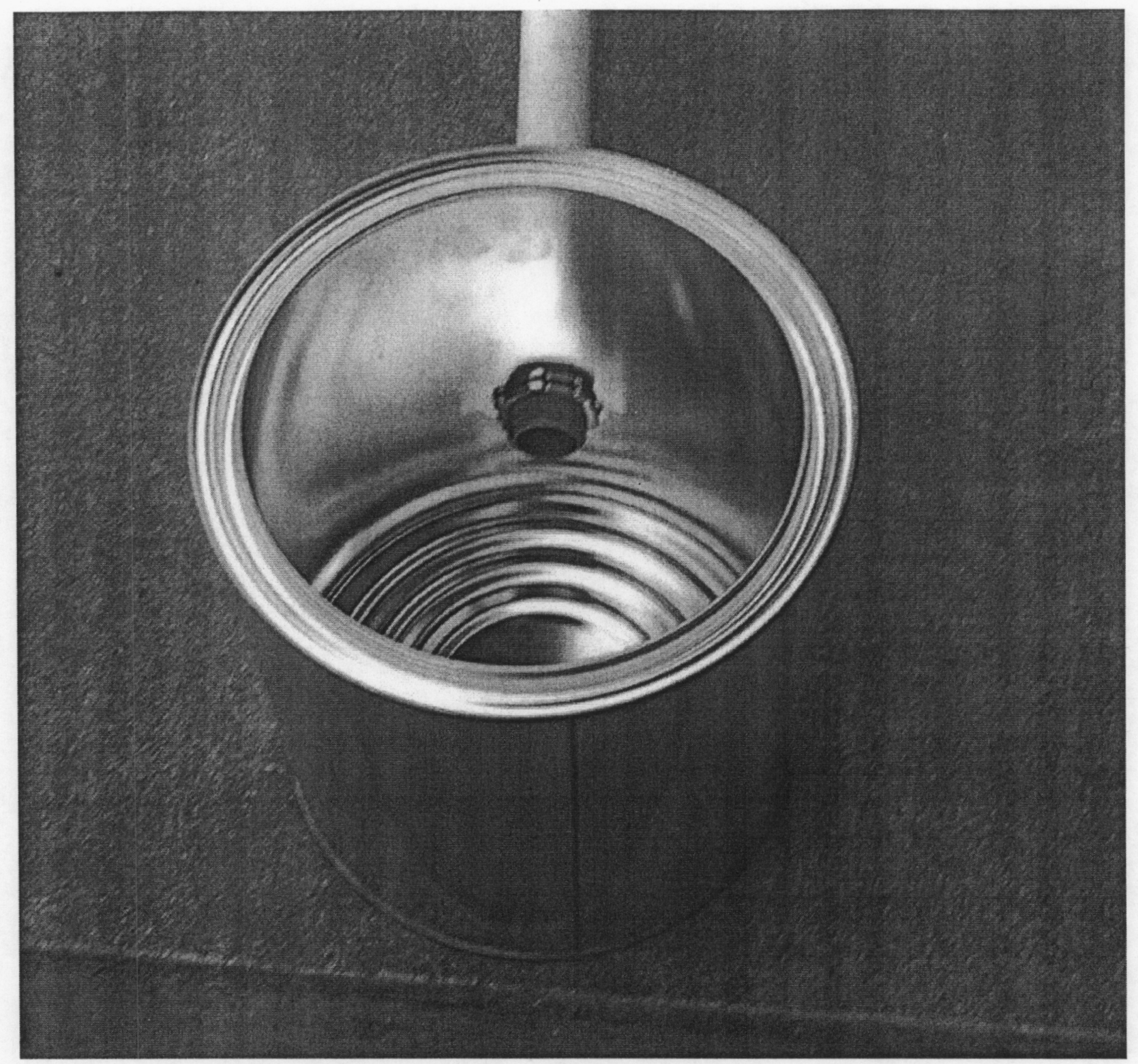

Figure 5. Test port of apparatus (1-gallon paint can) 


\section{Appendix A. Test results for nitromethane diluted with water}

There were 503 tests of nitromethane and diluted nitromethane samples. The results are presented in Table 1. The apparent threshold for reliable detection is between $10^{-12}$ and $10^{-14}$ atmospheres. The data are taken from [1].

Table 1. Detection results for water-diluted nitromethane solutions

\begin{tabular}{|c|c|c|c|}
\hline $\begin{array}{c}\text { Nitromethane Vapor } \\
\text { Pressure Range (microns) }\end{array}$ & $\begin{array}{l}\text { Number of Dog/ } \\
\text { Handler Teams }\end{array}$ & Total Tests & $\begin{array}{l}\text { Total Positive } \\
\text { Responses }\end{array}$ \\
\hline $\begin{array}{c}4 \times 10^{4} \begin{array}{c}\text { (pure nitromethane) } \\
\left(5.3 \times 10^{-2} \mathrm{~atm}\right)\end{array} \\
\end{array}$ & 12 on $5 / 8 / 01$ tests & 17 & $16(94 \%)$ \\
\hline 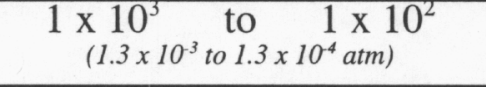 & $\begin{array}{l}12 \text { on } 9 / 18 / 00 \text { tests } \\
12 \text { on } 11 / 27 / 00 \text { tests }\end{array}$ & 44 & $40(91 \%)$ \\
\hline $\begin{array}{c}3 \times 10^{1} \text { to } 3 \times 10^{0} \\
\left(3.9 \times 10^{-5} \text { to } 1.3 \times 10^{6} \mathrm{~atm}\right)\end{array}$ & $\begin{array}{l}12 \text { on } 9 / 18 / 00 \text { tests } \\
12 \text { on } 11 / 27 / 00 \text { tests }\end{array}$ & 36 & $26(72 \%)$ \\
\hline $\begin{array}{c}3 \times 10^{-1} \text { to } 1 \times 10^{-2} \\
\left(3.9 \times 10^{7} \text { to } 1.3 \times 10^{8} \text { atm }\right)\end{array}$ & $\begin{array}{l}12 \text { on } 9 / 18 / 00 \text { tests } \\
12 \text { on } 11 / 27 / 00 \text { tests }\end{array}$ & 48 & $41(85 \%)$ \\
\hline 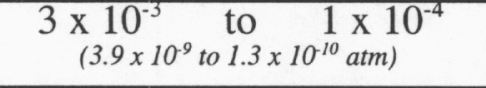 & $\begin{array}{l}12 \text { on } 9 / 18 / 00 \text { tests } \\
12 \text { on } 11 / 27 / 00 \text { tests }\end{array}$ & 42 & $37(88 \%)$ \\
\hline $\begin{array}{c}1 \times 10^{-3} \text { to } 1 \times 10^{-6} \\
\left(1.3 \times 10^{-11} \text { to } 1.3 \times 10^{-12} \text { atm }\right) \\
\end{array}$ & $\begin{array}{c}12 \text { on } 11 / 27 / 00 \text { tests } \\
5 \text { on } 3 / 7 / 01 \text { tests } \\
\end{array}$ & 79 & $68(86 \%)$ \\
\hline $\begin{array}{c}3 \times 10^{-7} \text { to } 1 \times 10^{-8} \\
\left(3.9 \times 10^{-13} \text { to } 1.3 \times 10^{-14} \mathrm{~atm}\right)\end{array}$ & $\begin{array}{l}5 \text { on } 3 / 7 / 01 \text { tests } \\
12 \text { on } 5 / 8 / 01 \text { tests }\end{array}$ & 96 & $44(46 \%)$ \\
\hline $\begin{array}{c}3 \times 10^{-9} \text { to } 1 \times 10^{-9} \\
\left(3.9 \times 10^{-15} \text { to } 1.3 \times 10^{-15} \mathrm{~atm}\right)\end{array}$ & $\begin{array}{l}5 \text { on } 3 / 7 / 01 \text { tests } \\
12 \text { on } 5 / 8 / 01 \text { tests }\end{array}$ & 41 & $28(68 \%)$ \\
\hline $\begin{array}{c}3 \times 10^{-11} \text { to } 3 \times 10^{-13} \\
\left(3.9 \times 10^{-17} \text { to } 3.9 \times 10^{-19} \mathrm{~atm}\right)\end{array}$ & 12 on $5 / 8 / 01$ tests & 68 & $44(65 \%)$ \\
\hline
\end{tabular}


Appendix B. Numerical results for 1 to 5-foot pipe lengths.

Table 1. Arrival time in minutes for various vapor pressures. Expected threshold based on data taken with water-diluted nitromethane is between $10^{-12}$ and $10^{-14}$ atmospheres

\begin{tabular}{|c|c|c|c|c|c|}
\hline $\begin{array}{c}\text { L, } \\
\text { feet }\end{array}$ & $\begin{array}{c}\text { Vapor Pres. } \\
\mathbf{1 0 ^ { - 6 }} \mathbf{~ a t m ~}\end{array}$ & $\begin{array}{c}\text { Vapor Pres. } \\
\mathbf{1 0 ^ { - 8 }} \mathbf{~ a t m}\end{array}$ & $\begin{array}{c}\text { Vapor Pres. } \\
\mathbf{1 0}^{-\mathbf{- 1 0}} \mathbf{~} \mathbf{t m}\end{array}$ & $\begin{array}{c}\text { Vapor Pres. } \\
\mathbf{1 0}^{-12} \mathbf{~} \mathbf{t m}\end{array}$ & $\begin{array}{c}\text { Vapor Pres. } \\
\mathbf{1 0}^{-\mathbf{1 4}} \mathbf{~} \mathbf{t m}\end{array}$ \\
\hline 1 & 4.6 & 3.1 & 2.3 & 1.8 & 1.5 \\
\hline 2 & 18.5 & 12.2 & 9.1 & 7.2 & 6.0 \\
\hline 3 & 41.7 & 27.5 & 20.5 & 16.3 & 13.5 \\
\hline 4 & 74.1 & 49.0 & 36.5 & 29.0 & 24.1 \\
\hline 5 & 115.8 & 76.5 & 57.0 & 45.3 & 37.6 \\
\hline
\end{tabular}

\section{References}

1. R. Strobel and J. Kury, "Nitromethane K-9 Detection Limit," 2001.

2. H. S. Carslaw and J. C. Jaeger, Conduction of Heat in Solids, Second ed. Oxford: Clarendon Press, 1959.

3. R. B. Bird, W. E. Stewart, and E. N. Lightfoot, Transport Phenomena. New York: John Wiley \& Sons, 1960.

4. R. C. Weast, Handbook of Chemistry and Physics, 53rd ed. Cleveland, $\mathrm{OH}$ : The Chemical Rubber Co., 1972. 